\title{
Design principles for risk-pooling systems
}

\author{
Lee Cronk $\circledast^{1 凶}$ and Athena Aktipis $\circledast^{2}$
}

\begin{abstract}
In times of crisis, risk pooling can enhance the resilience of individuals, households and communities. Risk-pooling systems are most effective when their participants adhere to several principles: (1) participants should agree that the pool is for needs that arise unpredictably, not for routine, predictable needs; (2) giving to those in need should not create an obligation for them to repay; (3) participants should not be expected to help others until they have taken care of their own needs; (4) participants should have a consensus about what constitutes need; (5) resources should be either naturally visible or made visible to reduce cheating; (6) individuals should be able to decide which partners to accept; and (7) the scale of the network should be large enough to cover the scale of risks. We discuss the cultural and evolutionary foundations of risk-pooling systems, their vulnerabilities and their relationship to commercial insurance.
\end{abstract}

S ince the earliest days of our species, the ability to manage risk has been critical for survival in uncertain and changing environments plagued by catastrophes and other unpredictable, costly events. Risk pooling is an informal social-insurance system that can protect against unexpected losses. Risk-pooling systems have arisen independently in societies around the world and have converged repeatedly on a set of principles that help buffer individuals and communities against risk. In this Perspective, we lay out seven design principles for effective risk-pooling systems that are based on the existing literature. We also discuss how these risk-pooling systems are employed by small-scale societies to increase their resilience in the face of negative events and how risk-pooling systems can help protect against unexpected losses in modern market-integrated societies.

Risk pooling is one of several strategies that humans use to manage risk. Risk pooling is a form of risk transfer, and risk transfer is the only risk-management strategy that requires social interaction. This is in contrast to strategies such as self-insuring by stockpiling resources, avoiding risky situations (for example, staying home during a pandemic) and taking precautions to reduce risks (for example, washing one's hands during a pandemic), none of which requires social interaction ${ }^{1}$. Conversely, risk transfer involves sharing risk with others ${ }^{2}$. Risk transfer involves the exchange of a small probability that one might experience a catastrophic loss for the high probability that one will experience small, manageable losses ${ }^{3}$. Modern insurance policies are a form of risk transfer that illustrates this point. When one buys an insurance policy, one accepts the necessity of regular small losses in the form of premium payments because one will receive support in the event of a catastrophic loss.

Along with innovations such as tool use and the controlled use of fire and language, informal risk pooling in the form of central-place provisioning was one of the key behavioural adaptations that differentiated our ancestors from related species ${ }^{4-6}$. Rather than foraging primarily on our own and sharing food only occasionally, as our closest nonhuman relatives do, our ancestors developed a system whereby individuals forage separately or in small groups, eating as they go but also bringing any surplus back to camp so that those who were unlucky and those who were too young, old, ill or injured to forage would still have something to eat ${ }^{7}$. The safety net created by central-place provisioning also made it possible for some individuals to focus on high-risk, high-reward foods such as large game, which, when captured, are shared widely. In this way, not only bad outcomes (for example, food shortages) but also good ones (for example, large game) were pooled. These risk-pooling systems probably also contributed to human life history and fertility patterns, with many individuals in communities helping to subsidize the nutritional needs of children and parents of young children ${ }^{8}$. Evidence from laboratory experiments is consistent with these patterns, whereby people are predisposed to share with others when there is unsynchronized variability in the availability of resources ${ }^{9-11}$.

Risk pooling among foragers is not limited to central-place provisioning. For example, the Ju/'hoansi of Namibia and Botswana have a system of partnerships known as hxaro. Because hxaro relationships are great responsibilities, people enter them only after a period of deliberation following an initial gift. Once established, hxaro partnerships are maintained over time and long distances through the periodic exchange of small gifts of non-food items such as beads, arrows and ostrich eggshells. When people experience shortages of food or water in one location, they can ask their hxaro partners living in other, more fortunate locations for help ${ }^{12}$.

People with means of subsistence other than foraging have also developed risk-pooling systems. Pastoralists in Africa ${ }^{13-17}$ and elsewhere ${ }^{18}$ pool risk by supporting one another in the event of livestock losses due to droughts, diseases and theft. Maasai and other Maa-speaking pastoralists refer to their risk-pooling system by their term for a human umbilical cord: osotua (plural: isotuatin) $)^{19-22}$. Many osotua partnerships begin in childhood, when Maasai parents encourage their children to form friendships known as isirito (singular: esirit). Children in such friendships share food and exchange small gifts. Such friendships eventually lead to exchanges in adulthood of more valuable gifts, which may lead to the formation of osotua partnerships. The process is similar to courtship, with prospective partners getting to know each other over several years. Osotua partnerships can also form in adulthood, typically beginning with a request for a gift or a favour. Although the rules of the osotua system are unwritten, they are quite formal and specific. For example, requests for aid from one's osotua partners must arise from one's genuine need and are limited to the amount actually needed. Gifts given in response to such requests must be given freely (pesho) and from the heart (ol-tau) and are limited to what is actually needed. Although in other circumstances, Maasai often do give each other gifts that create debts (esile), osotua gifts do not create debt,

'Department of Anthropology, Rutgers University, New Brunswick, NJ, USA. ²Department of Psychology, Arizona State University, Tempe, AZ, USA.

凶e-mail: leecronk@rutgers.edu 
Table 1 | Selected examples of risk pooling from the ethnographic literature

\begin{tabular}{l} 
Society and location \\
\hline Ache, Paraguay
\end{tabular}

American ranchers, United States

Batek, Malaysia

Dassanech, Ethiopia and Kenya

Dolgan and

Nganasan, Siberia

Fijians, South Pacific

Great Andamanese, Andaman Islands

Hadza, Tanzania

Hiwi, Venezuela

Huaorani, Ecuador

Jie and Turkana,

Uganda and Kenya

Karimojong, Uganda

Koryak, Russian Far East

!Kung/Ju/'hoansi/

Bushmen, Namibia and Botswana

!Kung/ Ju/'hoansi/

Bushmen, Namibia

and Botswana

Maasai, East Africa

Meriam, Australia

Mistassini Cree,

Canada

Nayaka, India

Ongee, Andaman

Islands

Pintupi, Australia

Foraging

Food shortages

Quechua, Peru

Pastoralism

Livestock deaths

Toba, Argentina

Foraging

Food shortages

Washo, Lake Tahoe
Food shortages
Food sharing

Livestock gifts

Food sharing

\section{Type of risk}

pooling

Food sharing

General support

Food sharing

Stock partnerships

Food sharing

General support

Food sharing

Food sharing

Food sharing

Food sharing

Stock partnerships

Stock

partnerships

General support

Food sharing

General support

Stock

partnerships

Food sharing

Food sharing

Food sharing

Food sharing

Food sharing
Example and source

"Although these individuals may not receive the same amounts they give (that is, strict Tit-for-Tat), one explanation for their generosity is that they receive additional food during hard times" (p. 263) ${ }^{69}$

"If there's any major occurrence that happens these little communities all come together to take care of those left behind, clean their houses, feed them, really amazing" (quote from an interviewee) $)^{82}$

"Batek share most food. Hunters give portions of meat to nearby households and to every family in a small camp. Gatherers share their products with all in need" (p. 300) $)^{133}$

"...general goodwill is supposed to over-ride precise reciprocity" (p. 120) ${ }^{13}$

"This ethic of sharing... means that certain individuals supply resources through kinship and friendship networks, often in a sustained one-way flow" (p. 48) $)^{134}$

"A kerekere is a request for a good accompanied by an implicit obligation on the part of the requestor to reciprocate should the potential donor wish to kerekere in return. But kerekere is not necessarily one side of a reciprocal transaction. It can be used repeatedly to effect a flow of goods from the affluent to those who are leqa, 'in need" (pp. 145-146) ${ }^{135}$

"Everyone who has food is expected...to give to those who have none... practically all of the food obtained is evenly distributed throughout the whole camp" (p. 43) $)^{136}$

"The meat cannot, in general, be directed to past donors or potential future donors. It has to be given to everybody in the camp, whether or not they are effective hunters with the capacity to give in future" (p. 49) 84

"Typically, these [food] products are shared; some of the food is offered to every person in the camp" (p. 98) ${ }^{137}$

"Food-sharing in the longhouse is not reciprocal: the actions of giving and receiving are entirely dissociated... Such non-reciprocal relations produce a collectivity in which givers never become creditors, nor receivers debtors" (p. 103) ${ }^{85}$

"A bond-friend is a person with whom one formally contracts [reciprocal stock] rights for reasons of mutual convenience and trust" (p. 209) $)^{17}$

"Any adult with reasonable cattle assets expends them in part on creating formal bonds of mutual friendship and assistance with non-relatives" (p. 92) ${ }^{16}$; see also ref. ${ }^{138}$

"In the North... a loner doesn't survive. That's why we support each other. We help each other" (p. 141; quote from an interviewee) $)^{139}$

"Meat sharing...is...not necessarily appreciated or reciprocated, and other food sharing is carried out quietly and there doesn't seem to be any scorekeeping involved" (p. 188) $)^{140}$

"...the !Kung system of reciprocity called $h x a r o . .$. is used to keep a wide range of contacts and possibilities open in the face of a highly variable environment..." (p. 62) ${ }^{12}$

Gifts are given between osotua partners in response to requests based on need; 'debt' and 'payment' are not part of the vocabulary of osotua relationships, ${ }^{1,9}$

"There are strong social sanctions against conditional or contingent sharing of 'table food' between households following a harvest of wild or cultivated resources"72

"A man is expected to give of both his time and food to others, especially those in dire straits" (p. 120) $)^{141}$

"Resources are always shared within the family, and between families if requested" (p. $258)^{142}$

"Each evening when the men return to the camp with the kill of their hunt and the women return with what they have gathered, all the food is placed in the middle of the camp at the communal cooking place. All Ongees are expected to just pick up whatever food there is irrespective of who brought it and who is or is not related to the person who either hunted or gathered it" (p. 18) $)^{143}$

"Men hunted alone or in small groups. A hunter distributed large game to all domestic units of the residential group" (p. 349) ${ }^{144}$

"Among ayllu [community] members, mutual aid is given freely because adherence to the principle of ayni [symmetrical reciprocity] is too universal for cheating to occur. Sunay, gift giving without the expectation of reciprocation, may have grown out of ayni" (p. 193) ${ }^{18}$

"Generalized reciprocity is the main means through which foodstuffs are socially distributed, often to meet the survival demands of those households suffering the harshest poverty" (p. 112) $)^{145}$

"[sharing] is characterized by the attitude that each person will do what is appropriate, not by an expectation of equivalent return as in reciprocity" (p. 6) ${ }^{146}$ 
and it is also considered inappropriate to use the word 'to pay' (alak) in the context of an osotua gift. Osotua relationships do not follow a schedule, and they persist even if much time passes between gifts. There is no expectation of a balance of gift-giving between osotua partners. Thus, the flow of goods and services between partners might be mostly or entirely one-way if that is where the need is greatest. Finally, osotua is imbued with respect (enkanyit), restraint and responsibility in a way that non-osotua economic relationships are not. As one interviewee put it: "It is heavy" (keiroshi).

Although risk transfer in societies with advanced economies is mostly accomplished through commercial insurance and the state, risk pooling was very important in the recent past and continues to be important in some quarters. For example, fraternal organizations and industrial sickness funds were widespread and important in nineteenth and early-twentieth century United States and Britain $^{23-26}$. Individuals voluntarily joined these organizations and contributed small amounts of money at regular intervals to a fund that then would be available for members who were in need. Such organizations provided services such as sick-leave benefits, health insurance, life insurance, funeral insurance and care of orphans of deceased members.

With the rise of both the welfare state ${ }^{27}$ and commercial insurance $^{28}$, fraternal organizations shrank, but, in the contemporary United States, healthcare-sharing ministries play a similar role by forming groups that agree to pay each other's medical expenses ${ }^{29}$. Even today, both informal and formal risk pools exist in such societies. In the European country of Andorra, a risk pool called $\mathrm{La}$ Crema provides mutual fire insurance to its members ${ }^{30}$. In parts of Ethiopia and Tanzania, formal risk-pooling organizations provide funeral insurance ${ }^{31}$. Mutual aid systems involving risk pooling have been documented many times among North American farmers and ranchers ${ }^{32-41}$ and among the urban poor in the United States ${ }^{42,43}$. On the Pacific coast of the United States, fishermen pool their by-catch (that is, fish caught unintentionally that are subject to a government-imposed quota) so that each one can continue fishing as long as possible each season ${ }^{44}$. Around the world, people form lottery syndicates in which they purchase tickets together and share in any winnings ${ }^{45}$. In the United States, a for-profit risk-pooling system has been developed by a company called Pando. Pando creates voluntary risk pools among young baseball players and people in other professions whose future fortunes are difficult to predict and then helps enforce those risk pools by monitoring the future income of participants.

Risk can be managed and shared in many different ways. The most straightforward situation is one in which risks are borne solely by an individual or group. In systems such as the Pando risk-pool described above, for example, individuals voluntarily opt into risk pools in which risk is shared among members. However, there are many situations in which risk can spread widely and affect individuals who have not voluntarily taken on risk ${ }^{46}$. Whenever individuals or institutions are highly interdependent, catastrophic events can reverberate through these systems and through society more broadly. This also makes the effective management of risk essential in modern, financially developed societies ${ }^{47}$.

Anthropologists, economists and others have studied risk-pooling systems for decades, yielding a large body of scholarship on many different such systems and numerous insights into what makes them succeed or fail ${ }^{48-80}$. The situation is analogous to one that occurred several decades ago in the study of common pool resource management when, after years of research, Ostrom and colleagues were able to specify a list of design principles for such systems ${ }^{81}$. Risk-pooling systems also have several shared features across societies that contribute to their success in helping individuals and communities manage risk.

Many of the examples we use to illustrate these design principles of risk-pooling systems are from Africa, where high cultural and linguistic diversity and a relative lack of market integration have left many local risk-pooling systems intact, and they have been studied by ethnographers. But risk-pooling systems are pervasive in small-scale societies and have been well documented in many other parts of the world (Table 1).

There are seven design principles for risk-pooling systems that emerge from empirical work from the past several decades.

\section{Principle 1: participants should agree that the pool is for needs that arise unpredictably, not for routine, predictable needs}

Across many societies, risk pooling occurs for needs that arise unpredictably. For example, in the Malpai region of southeastern Arizona and southwestern New Mexico, ranches help each other in a system known as 'trading work' or 'neighbouring. In the case of branding, transporting livestock and other needs that they can schedule in advance, most ranchers who help their neighbours expect the favour to be returned. However, when needs arise unpredictably, as in the case of an illness, injury or death of a family member, neighbours step up and provide help with no expectations of anything in return other than a similar favour if they are ever in need for a similarly unpredictable reason ${ }^{82}$ (Fig. 1a).

This pattern is not unique to the American Southwest. Across many societies, people believe that those who unpredictably become needy and through no fault of their own are deserving of aid. For example, although Denmark has a more generous welfare state than the United States, both Danes and Americans tend to agree that people who are needy through no fault of their own deserve help, while those who are needy as a result of laziness do not ${ }^{83}$.

\section{Principle 2: giving to those in need should not create an obligation for them to repay}

An important design principle of risk-pooling systems is that transfers to those in need should not create an obligation for repayment, although they can create a mutual obligation to help one another in times of need. Successful risk pooling requires people to be tolerant of imbalances between the aid that they give to and receive from others, a characteristic of both the osotua ${ }^{19}$ and hxaro ${ }^{12}$ systems, as well as many others (Table 1). Particularly among hunter-gatherers, this principle is often culturally instantiated in the form of a strong ethic of sharing without any expectation of repayment. Hadza huntergatherers in Tanzania go so far as to say plainly: "We have no debt" (Fig. 1b). Elsewhere in Tanzania, De Weerdt and Fafchamps ${ }^{50}$ examined data on informal transfers and loans in an agricultural village, looking for "tell-tale signs of limitations imposed by reciprocal arrangements among self-interested individuals." They found no such signs, instead finding the data "consistent with altruism or social norms" in which gifts do not create debt. This pattern of non-reciprocal helping occurs in South American small-scale societies, including the Ache ${ }^{69,73}$, Quechua ${ }^{18}$ and Huaorani ${ }^{85}$, as well as many other societies around the world (Table 1).

In a computer simulation of Maasai livestock-transfer systems, the need-based osotua rules outperformed the debt-based esile rules. In the need-based system, agents give to partners in need without any requirement that their gifts be repaid, while in the debt-based system, agents end relationships if partners do not repay within a limited time frame. The need-based system was found to pool risk more effectively and lead to greater herd survival than the debt-based system ${ }^{86-88}$. The reason for this is simple: because agents following a debt-based rule end relationships with agents who fail to repay their loans, they have fewer other agents from whom they can request help when they are at risk of falling below the threshold for survival. Agents that follow a need-based strategy, in contrast, maintain all their relationships because they do not expect repayment-only similar help if they themselves are in need. 


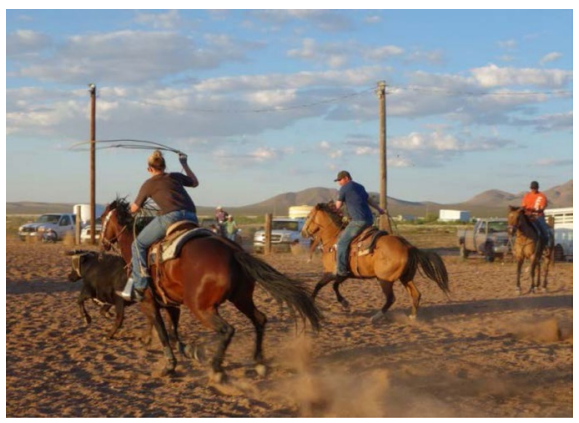

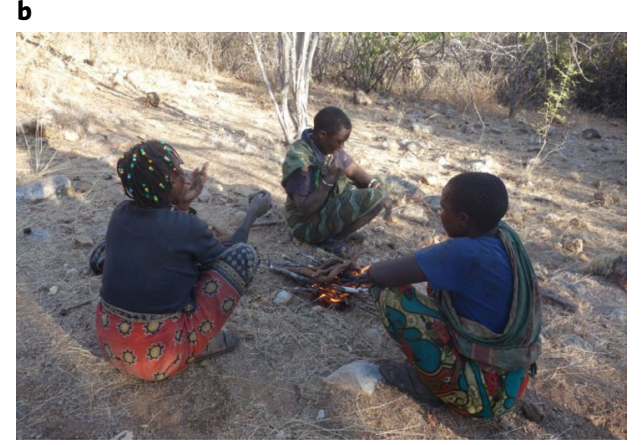

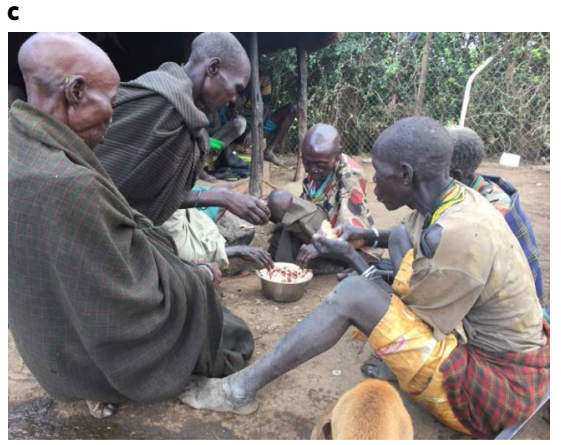

Fig. 1 | Examples of risk-pooling behaviours. a, Roping steers near Animas, New Mexico. Ranchers in the southwestern United States help each other with both predictable chores and in the aftermaths of unpredictable events, such as injuries, as described in design principle (1). b, Hadza women sharing tubers in Tanzania. This is an example of a strong ethic of sharing, described in design principle (2). c, Ik women sharing food in Uganda. Ik sharing norms have broken down, but subsequently been recovered during times of severe famine, as described in the Discussion. Photograph in c reproduced with permission from Cathryn Townsend.

\section{Principle 3: participants should not be expected to help others until they have taken care of their own needs}

In challenging situations, it is often important that people take care of their own needs before helping others. This is the case in small-scale societies, including hunter-gatherers, pastoralists and agriculturalists. It is also the case for many aspects of life in industrialized societies. For example, the safety briefing on airplanes always includes the direction to put on your own oxygen mask first before helping others. People who put their own survival in jeopardy by helping others can generate greater risk for the entire system, whether it is an emergency response on an airplane or a small-scale society managing uncertain foraging returns.

The idea that participants in risk pools should take care of their own needs before helping others was the main finding of an early computer simulation of such systems ${ }^{89}$. Hegmon created a simulation of Hopi agriculture and modelled three possible crop-sharing systems: no sharing at all; pooling all resources within groups of five households without first setting aside enough within each household to meet its needs; and sharing of resources with needy households only after a household's own needs were met. Independent households that shared nothing and received nothing fared worst of all. Those that shared everything regardless of whether they were able to meet their own needs fared somewhat better, but those that shared only after their own needs were met fared the best of all.

Small-scale societies follow this pattern of individuals taking care of their basic needs before helping others. Among foragers, this rule takes the form of eating while you are foraging, which ensures that you yourself will have enough food, but continuing to forage after you have eaten enough and bringing home this surplus to share with those who did not find enough food ${ }^{7}$. Among pastoralists, this takes the form of taking good care of your own herds, keeping them as large and healthy as possible so that they are available not only for your own needs but also those of your risk-pooling partners should they become needy. One important rule of the Maasai osotua system is that osotua partners are allowed to refuse a request of aid if fulfilling it would put them at risk of going below the threshold for what they would need for the survival and well-being of their own family.

\section{Principle 4: participants should have a consensus about what constitutes need}

Because risk-pooling is predicated on the idea that aid should go only to those who actually need it, disagreements regarding what constitutes real need can undermine the system. This means that it is necessary for participants in the pool to agree on what needs individuals can ask for help for (for example, essential needs such as having enough food for one's family) and what things are not essential enough to be worthy of help within the risk pool. The tremendous variations in standards of living that exist not only around the world but even within small areas can be a serious obstacle to successful risk-pooling. When risk pooling takes place on very small scales, as among foragers, this problem may be easy to overcome because there is little variation in wealth ${ }^{90}$. Among the Maasai, this problem is overcome via a certain degree of residential and social segregation in which poor Maasai and wealthy Maasai tend to live in separate areas and form separate risk pools with those who have similar attitudes about what constitutes basic needs. In market-integrated societies with high levels of income and wealth inequality, it may be difficult to create a single risk-pooling network in which participants agree about what constitutes genuine need.

\section{Principle 5: resources should be either naturally visible or made visible to reduce cheating}

Like most cooperative systems, risk-pooling systems are vulnerable to cheating. When it is possible to hide resources, people may take advantage of the opportunity to cheat. When participants play a resource-management game that simulates life as a Maasai herder and are given the opportunity to ask for help and to provide help in the event of a shock, having visible rather than hidden resources reduces cheating ${ }^{91}$

Cheating in such systems can take two forms: asking for help when one does not really need it (greediness) and refusing to help when one is actually able to help without putting oneself at risk (stinginess). In the long run, cheating in a risk-pooling system can lead to a natural consequence punishment, whereby no one is available to help cheaters when they find themselves in need. But in the short run, cheating in such systems may still be lucrative and tempting. However, it is not possible to cheat by lying about what one needs or has to offer when resources are easy to see. Among hunter-gatherers and pastoralists, the resources that are most important to them (dead and living large animals, respectively) are inherently difficult to hide, which makes it difficult to be greedy or stingy without it being obvious to others.

In market-integrated societies, where it is easy to hide wealth (for example, in a bank account), it may be more challenging to create successful risk-pooling systems. One solution can be to require that participants in risk pools reveal their wealth. This is the strategy being used by Pando, a US company that creates risk pools among people in occupations, such as professional baseball, in which it is difficult to predict who will become very wealthy. In the case of Major League Baseball, contracts of all the players are public 
knowledge, which makes it impossible to hide income. Pando also creates other risk pools in industries where income is not public knowledge. To prevent cheating by hiding wealth in these industries, they require participants to share their income tax returns (E. Lax, personal communication).

\section{Principle 6: individuals should be able to decide which partners to accept}

In general, cooperation is more successful and sustainable when individuals are able to choose which partners to interact with ${ }^{92}$. Partner choice helps stabilize cooperation by allowing cooperators to preferentially interact with other cooperators so that cooperators gain the benefits of interacting with one another. Furthermore, partner choice allows cooperation to be grounded in shared norms, reputations and mutual trust, all of which have been shown to be fundamental to the success of large-scale cooperative networks (for example, folk lending and private banking in Asia) ${ }^{93,94}$. In the Maasai osotua system and similar systems in other societies, individuals have a great deal of autonomy with regard to who their partners will be. This allows individuals to find others who have similar attitudes towards risk and other traits that make them compatible risk-pooling partners. Among the Maasai, the long process of cultivating osotua partners helps ensure compatibility in terms of risk taking among partners and other aspects of livestock management. It also probably provides them with ample time to assess the work ethic and trustworthiness of potential partners. If individuals were not allowed to choose their risk-pooling partners, this would exacerbate the problem of moral hazard, compromising incentives to wisely manage resources and risk.

\section{Principle 7: the scale of the network should be large enough to cover the scale of risks}

In an ideal risk pool, the scale of the network is such that individuals are exposed to different kinds of risks and experience them at different times ${ }^{95}$. Having a network that is large and diverse can help insulate risk-pooling networks from widespread shocks. For example, Bollig ${ }^{14}$ conducted a livestock census among pastoralist Pokot in western Kenya before, during and after a drought. Although the average herd in his sample shrank during the drought, several of them grew. The topography of East Africa features great altitudinal variations within short distances that help reduce the correlation of shocks among risk-pooling partners ${ }^{96}$. High-altitude regions are generally well watered and so provide livestock with water and forage, but they also harbour more livestock diseases. Low-altitude areas are a good complement: although they do not provide as much food and water, they typically have low rates of livestock diseases. Maasai and other East African pastoralists are well aware of this, and they strive to develop risk-pooling partnerships with people who live in areas that are ecologically different from their own ${ }^{17}$.

When individuals in a specific region encounter the same shocks at the same times, scaling up the risk-pooling system can help reduce the synchronicity of shocks. Increasing the number of participants and including individuals who are in different geographical areas are two ways to do this. Because the enforcement of the risk-pooling agreement may be more difficult over long distances, this can be a major challenge $e^{97}$. However, some risk-pooling systems do have some built-in flexibility, with the scale of helping being based on the scale of particular risks and needs. For example, Fijian islanders adjust the social and physical distances between themselves and the people they ask for help depending on whether the need is very local or more widespread. When illnesses and injuries occur, people ask those close at hand, such as close kin, but when widespread disasters such as droughts and cyclones strike, they draw on ties to distant kin in other villages where the impact of the disaster may have been less severe ${ }^{1}$.

\section{Discussion}

Risk pooling systems can fail when there are not enough resources to meet basic needs. Risk-pooling systems can fail when there are simply not enough resources for individuals to meet their own basic need (violating principle (2)) and when the scale of the network is not large enough to buffer against synchronous shocks (violating principle (7)). For example, during a 19-year period in the late-nineteenth and early-twentieth centuries, the Maasai experienced a series of temporally correlated shocks that they call Emutai, meaning the wiping out ${ }^{98}$. Emutai was caused by a combination of drought and epidemics among both humans and their livestock and led to a breakdown of social relations and civil war among the Maasai. But eventually they recovered, and osotua relationships once again became an essential aspect of Maasai risk management. A similar situation occurred among the Ik of Uganda. Ik culture includes a strong ethic of sharing summarized by the adage tomora maráy, meaning 'it's good to share ${ }^{39}$. In the 1960 s, the Ik were moved from their ancestral hunting grounds for the creation of a national park, which, combined with a drought, led to a severe famine. The resulting starvation led people to hoard what little food was still available and engage in other selfish behaviours ${ }^{100}$. After the famine passed, widespread sharing once again became the Ik norm $^{98,101}$ (Fig. 1c).

Risk-pooling systems are often imbued with sacred cultural, religious and social concepts. Many risk-pooling systems in small-scale societies are imbued with a sense of sacredness. For example, the Ik of Uganda believe in earth spirits known as kíjáwik ${ }^{a}$. Kíjáwik ${ }^{\mathrm{a}}$ are said to monitor the behaviour of people and then punish stingy people and reward generous people ${ }^{1,99}$. Even when a religion includes no belief in supernatural punishment, linking membership in a risk pool to participation in a religion might be a way to increase cooperation within the pool, as religion has been shown to do for other forms of cooperation ${ }^{102-105}$. The Maasai osotua system is also imbued with a sense of sacredness that may serve as an implicit threat of supernatural punishment against cheaters. The way that the word osotua evokes the sacred relationship between mother and fetus may also discourage cheating and encourage cooperation. The metaphorical use of kin terms such as brother or sister for risk-pooling partners might have a similar effect ${ }^{20,106}$.

Risk-pooling systems build on our evolved psychology. The psychological adaptations that underlie risk pooling through need-based helping may have first evolved in the context of parenting and other interactions with close kin, later becoming generalized for interactions with others. Need-based helping of offspring makes evolutionary sense because the fitness of parents is dependent on that of their offspring. Need-based helping of other kinds of close kin makes sense for essentially the same reason, that is, overlapping genomes due to shared ancestry ${ }^{107,108}$ and the resulting fitness interdependence ${ }^{109}$. Fitness interdependence can also arise due to other reasons, such as co-residence, and the logic of helping those with whom one is interdependent in ways other than genetic relatedness can be mathematically modelled in a way that is analogous to Hamilton's rule ${ }^{110,111}$.

If groups of early humans had shared fates and therefore high levels of fitness interdependence, selection may have favoured those who responded to the needs not only of close genetic relatives but also others with whom they shared high degrees of positive fitness interdependence. The resulting propensity to help others based on their need may have provided the foundation on which successful risk-pooling systems are built. Once risk pooling is established, it can in turn further increase interdependence among the members of the risk-pooling group. In this way, many different sources of interdependence-co-residence, kinship, marriage, risk pooling, and so on-can be mutually reinforcing as they provide multiple 

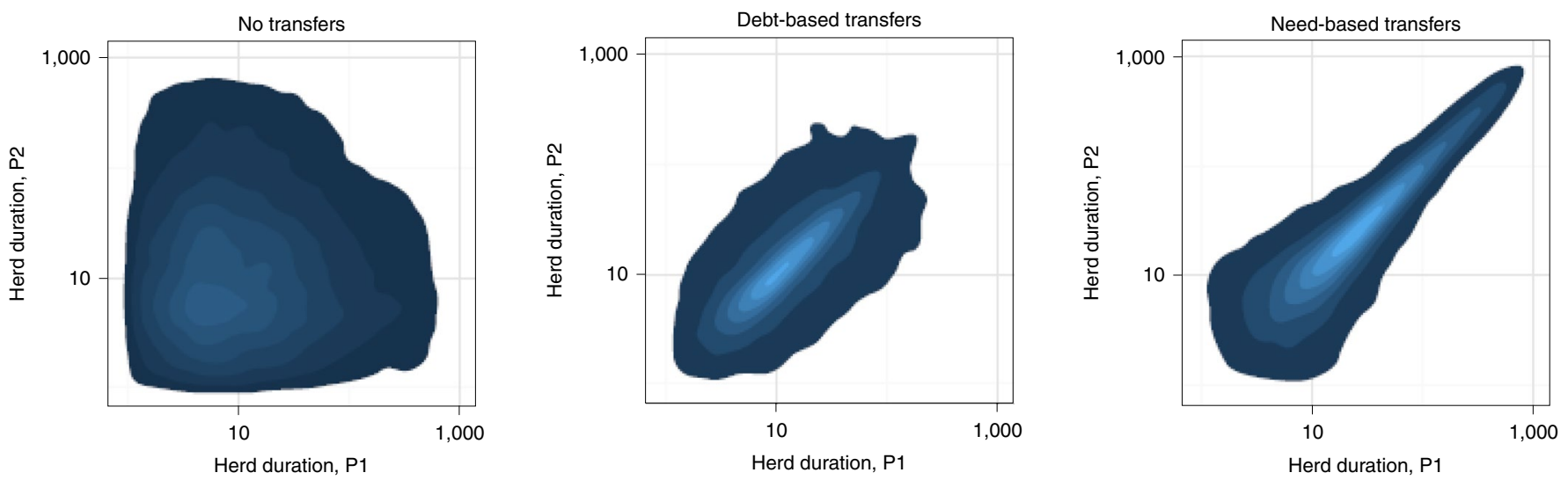

Fig. 2 | Herd duration in a dyadic agent-based model of risk pooling. Left to right: no transfers between agents, transfers that create debts that must be repaid or the relationship will end, and need-based transfers that create no debt. The axes represent how long herds remained above the threshold for survival for Player 1 (P1) and Player 2 (P2). The degree of risk pooling and survival are both greatest when agents follow a need-based strategy and do not require repayment. Adapted with permission from ref. ${ }^{87}$, Springer Nature.

reasons for people to look after one another by increasing the degree to which they have shared fates.

Risk-pooling systems often decline in response to market integration and increased affluence. When market integration gives people access to resources, such as cash, that can be easily hidden (violating principle (5)), even long-established risk-pooling systems can begin to falter. For example, after Mbuti hunter-gatherers in the Congo region began selling meat to traders, the amount of meat shared within camps decreased ${ }^{112}$. Similarly, the introduction of cash into Baka communities in Cameroon led to money hoarding and less meat sharing ${ }^{113,114}$.

Risk-pooling systems can also decline in importance simply because increased affluence and economic diversification make people less dependent on them. For example, among the Maasai in Tanzania, as the dependence of households on pastoralism decreases, their efforts to restock the herds of others declines, so does the frequency with which they give and receive gifts to and from other households ${ }^{115}$. Similarly, there has been a decline in risk pooling and a rise in patron-client relationships among Fulani in Nigeria as some households have become wealthy and others have remained poor ${ }^{95}$.

With market integration, debt-based transactions typically increase, while need-based transactions decrease. This does not mean that risk pooling is impossible; models show that some amount of risk pooling still does happen in debt-based systems, just not to the same extent that it does in need-based systems ${ }^{87}$ (Fig. 2). Successful debt-based risk-pooling systems take into account random shocks experienced by both borrowers and lenders. For example, in northern Nigeria, informal loans are usually made before the start of the growing season and repaid after the first crops are harvested. When borrowers experience losses due to floods, high winds or insects, lenders often give them extra time to repay and charge less interest ${ }^{116,117}$. When shocks occur to lenders, borrowers often increase the interest they pay. Similarly flexible debt-based systems have been documented in India ${ }^{118}$ and the Philippines ${ }^{119}$.

Other scholars have pointed out that financial development has increased some dimensions of risk because of incentive structures that encourage risk taking and risk transfer ${ }^{47}$. The ability of banks and other organizations to externalize many risks points to the need for building better self-governance structures that can deal with the networked nature of financial risk ${ }^{46}$. The principles of risk-pooling systems that we have laid out here might be helpful for redesigning these systems so that they are better able to deal with risk within their structures without leading to cascading effects in the networked financial system.

Risk pooling and commercial insurance can complement each other. Unlike commercial insurance, risk pooling does not require actuarial databases that allow companies to calculate the probabilities that specific kinds of people will experience specific kinds of $\operatorname{losses}^{28}$. As a result, grassroots risk-pooling arrangements have an advantage over commercial insurance. That is, while insurance policies are typically limited to very specific types of risk, risk-pooling arrangements can cover a wide range of types of risk, not all of which have to be specified at the outset. This makes risk pooling particularly useful for communities that may experience unexpected and unprecedented events.

However, as we have seen, risk-pooling systems have some vulnerabilities. In some circumstances, it may be possible to overcome some of those vulnerabilities by combining risk pooling with commercial insurance products. For example, index insurance can help when a risk-pooling network is not large enough to handle synchronous shocks (violating principle (7)). Index insurance is tied not to the fortunes of the purchaser but rather to some environmental variable, such as rainfall, that can be independently measured and that is known to correlate with the economic fortunes of the purchasers $^{120,121}$. In the past two decades, a system called index-based livestock insurance (IBLI) ${ }^{122}$ has provided Mongolian herders insurance against winter disasters (called $d z u d$ in Mongolian) that involve cold temperatures and severe storms that can kill millions of livestock. Payments are made when livestock mortality of a particular species in a district exceeds $5 \%$ or $6 \%$. An analysis of recovery of pastoralists after a severe dzud in the winter of 2009-2010 showed that households that purchased IBLI before the dzud recovered faster than uninsured households ${ }^{122}$.

Hybrid risk-pooling systems that incorporate features of both markets and need-based systems also have the potential to increase resilience. For example, the airline industry uses a seat-exchange system that allows airlines to buy seats from one another at below-market prices when uncontrollable circumstances such as bad weather and equipment failure require the cancellation of flights. This seat-exchange system is specifically for situations where need arises unpredictably. Although this system includes financial payments, these payments are below what would be charged on the open market. This system of seat exchange helps buffer the international air-transportation system against both minor uncertainties of weather and larger hazards such as natural disasters (E. Gel and 
M. Clough, personal communication). Even debt-based lending can have elements of need-based systems. For example, the Chettiar banking system in India had an inter-bank lending mechanism that was in place to help one another in times of need. Within this system, they would freely lend funds (at a lower rate than they typically lent) among one another when a bank was in need of liquidity ${ }^{93}$.

The complementarity of commercial insurance and risk pooling can also be seen in the wake of natural disasters and other unexpected catastrophes. In the aftermath of such events, those who are in a position to help often do so spontaneously and without any expectation of repayment. This helping often fills a critical gap by assisting with immediate needs that are not covered by commercial insurance. For example, in the aftermath of the 1906 San Francisco earthquake, many businesses did not charge for food and services ${ }^{123}$. After Hurricane Katrina devastated the US Gulf Coast in 2005, hundreds of volunteer boat owners, dubbed the 'Cajun Navy' by journalists, took it on themselves to rescue people from their flooded homes, sometimes at considerable risk to themselves ${ }^{124}$. During the current coronavirus pandemic, generosity has taken many forms, including people sewing masks for healthcare workers ${ }^{125}$, people shopping for those who are at high risk $^{126}$, people donating their stimulus cheques to food pantries and other charities ${ }^{127}$, landlords waiving rent ${ }^{128}$ and distilleries turning alcohol waste into hand sanitizer and then giving it away ${ }^{129}$.

Risk-pooling systems that utilize need-based transfers can potentially contribute to our resilience to disasters across systems of varying scales and complexities. As catastrophic events increase in frequency, the ability of standard insurance to really help people and organizations that are in need will continue to decline ${ }^{130}$. One possible solution would be to create an alternative to market-based insurance that is specifically geared towards building risk-transfer networks that allow individuals and organizations to insure against catastrophes. Such a system could operate even when pricing risk and insurance is not possible. Given the vulnerabilities of our current globalized financial system to spread risk, a restructuring of our formal and informal risk-management systems may be in order ${ }^{47}$. Future work should investigate how these systems can be effectively incorporated with market-based mechanisms to effectively employ them to enhance large-scale global hazard resilience.

\section{Conclusion}

This article was inspired in part by the example of the design principles for common pool resource management identified by Ostrom and colleagues ${ }^{81}$. However, while common pool resource management schemes have often been deliberately designed, most of the risk-pooling systems that researchers have documented simply emerged over time through interactions among people, similar to many other social rules and institutions ${ }^{131,132}$, and have probably evolved through a Darwinian process of selection among alternative culture traits. Even though the principles underlying risk-pooling systems were not deliberately designed to solve the problems of managing risk, they offer unique solutions for dealing with catastrophic situations that even deliberately designed risk-management systems such as market-based insurance cannot handle. As we as a society strive to create more effective strategies for managing risk in increasingly uncertain times, we may be able to leverage this ancient wisdom to better manage our modern risks.

Received: 6 May 2020; Accepted: 20 April 2021;

Published online: 27 May 2021

\section{References}

1. Cronk, L. et al. in Global Perspectives on Long Term Community Resource Management (eds Lozny, L. R. \& McGovern, T. H.) 41-75 (Springer, 2019).

2. Dorfman, M. S. Introduction to Risk Management and Insurance (Prentice Hall, 2007)
3. Cashdan, E. A. Coping with risk: reciprocity among the Basarwa of Northern Botswana. Man 20, 454-474 (1985).

4. Isaac, G. Ll. in Evolution from Molecules to Man (ed. Bendall, D. S.) 509-543 (Cambridge Univ. Press, 1983).

5. Cashdan, E. in Economic Anthropology (ed. Plattner, S.) 21-48 (Stanford Univ. Press, 1989).

6. Marlowe, F. W. Hunter-gatherers and human evolution. Evolut. Anthropol. 14, 54-67 (2005).

7. Berbesque, J. C., Wood, B. M., Crittenden, A. N., Mabulla, A. \& Marlowe, F. W. Eat first, share later: Hadza hunter-gatherer men consume more while foraging than in central places. Evol. Hum. Behav. 37, 281-286 (2016).

8. Kim, Hill \& Magdalena, HurtadoA. Cooperative breeding in South American hunter-gatherers. Proc. R. Soc. B Biol. Sci. 276, 3863-3870 (2009).

9. Kaplan, H. S., Schniter, E., Smith, V. L. \& Wilson, B. J. Risk and the evolution of human exchange. Proc. Biol. Sci. 279, 2930-2935 (2012).

10. Kameda, T., Takezawa, M., Tindale, R. S. \& Smith, C. M. Social sharing and risk reduction: exploring a computational algorithm for the psychology of windfall gains. Evol. Hum. Behav. 23, 11-33 (2002).

11. Kameda, T., Takezawa, M. \& Hastie, R. The logic of social sharing: an evolutionary game analysis of adaptive norm development. Pers. Soc. Psychol. Rev. 7, 2-19 (2003).

12. Wiessner, P. in Politics and History in Band Societies (eds Lee, R. B.. \& Leacock, E.) 61-84 (Cambridge Univ. Press, 1982).

13. Almagor, U. Pastoral Partners: Affinity and Bond Partnership Among the Dassanetch of South-west Ethiopia (Manchester Univ. Press, 1978).

14. Bollig, M. in Kinship, Networks, and Exchange (eds Schweizer, T. \& White, D. R.) 137-157 (Cambridge Univ. Press, 1998).

15. Bollig, M. Risk Management in a Hazardous Environment: A Comparative Study of two Pastoral Societies Vol. 2 (Springer, 2010).

16. Dyson-Hudson, N. Karimojong Politics (Clarendon Press, 1966).

17. Gulliver, P. H. The Family Herds: A Study of Two Pastoral Tribes in East Africa, the Jie and Turkana (Routledge and Kegan Paul, 1955).

18. Flannery, K. V., Marcus, J. \& Reynolds, R. G. The Flocks of the Wamani: A Study of Llama Herders on the Punas of Ayacucho, Peru (Academic Press, 1989).

19. Cronk, L. The influence of cultural framing on play in the trust game: a Maasai example. Evol. Hum. Behav. 28, 352-358 (2007).

20. Cronk, L., Steklis, D., Steklis, N., van den Akker, O. R. \& Aktipis, A. Kin terms and fitness interdependence. Evol. Hum. Behav. 40, 281-291 (2019).

21. Perlov, D. C Trading for Influence: The Social and Cultural Economics of Livestock Marketing Among the Highland Samburu of Northern Kenya. $\mathrm{PhD}$ thesis, Univ. California, Los Angeles (1987).

22. Spencer, P. The Samburu: A Study of Gerontocracy in a Nomadic Tribe (Univ. California Press, 1965).

23. Beito, D. T. From Mutual Aid to the Welfare State: Fraternal Societies and Social Services, 1890-1967 (Univ. North Carolina Press, 2000).

24. Beito, D. T. in The Voluntary City: Choice, Community, and Civil Society (eds Beito, D. T. et al.) 182-203 (Univ. Michigan Press, 2002).

25. Murray, J. E. Origins of American Health Insurance: A History of Industrial Sickness Funds (Yale Univ. Press, 2007).

26. Green, D. in The Voluntary City: Choice, Community, and Civil Society (eds Beito, D. T. et al.) 204-222 (Univ. Michigan Press, 2002).

27. Skocpol, T. Protecting Soldiers and Mothers (Harvard Univ. Press, 1995).

28. Levy, J. Freaks of Fortune: The Emerging World of Capitalism and Risk in America (Harvard Univ. Press, 2012).

29. Schwarz, C. Thrifting for more: savings and aspirations in health care sharing ministries after the Affordable Care Act. Med. Anthropol. Q. 33, 226-241 (2019).

30. Cabrales, A., Calvó-Armengol, A. \& Jackson, M. O. La Crema: a case study of mutual fire insurance. J. Polit. Econ. 111, 425-458 (2003).

31. Dercon, S., De Weerdt, J., Bold, T. \& Pankhurst, A. Group-based funeral insurance in Ethiopia and Tanzania. World Dev. 34, 685-703 (2006).

32. Anderson, T. L. \& Hill, P. J. The Not So Wild, Wild West: Property Rights on the Frontier (Stanford Univ. Press, 2004).

33. Bennett, J. W. Reciprocal economic exchanges among North American agricultural operators. Southwest. J. Anthropol. 24, 276-309 (1968).

34. Bennett, J. W. Northern Plainsmen: Adaptive Strategy and Agrarian Life (AHM Publishing, 1969).

35. Derby, J. T. Cattle, Kin and the Patrimonial Imperative: Social Organization on Nevada Family Ranches (Univ. California, Davis, 1988).

36. Ellickson, R. C. Order Without Law: How Neighbors Settle Disputes (Harvard Univ. Press, 1991).

37. Hagler, M., Hamby, S., Banyard, V. \& Grych, J. 'We almost had the whole block's phone number on the wall': a mixed methods investigation of informal helping in a predominantly rural sample. J. Community Psychol. 47, 477-494 (2018).

38. Ion, H. W. Pioneer virtues. Beneficence https://www. thephilanthropicenterprise.org/ wp-content/uploads/2015/01/ Beneficence2012-3-Ion-no-printer-marks.pdf (2012). 
39. Jobes, P. C. The disintegration of gemeinschaft social structure from energy development: observations from ranch communities in the western United States. J. Rural Stud. 3, 219-229 (1987).

40. Kimball, S. T. Rural social organization and co-operative labor. Am. J. Sociol. 55, 38-49 (1949).

41. Marshall, H. W., Ahlborn, R. E. \& National Museum of History Technology. Buckaroos in Paradise: Cowboy Life in Northern Nevada (Library of Congress, 1980).

42. Stack, C. B. All Our Kin: Strategies For Survival In A Black Community (Harper and Rowe, 1970).

43. Miller, M. L. The Alternative: Most of What You Believe About Poverty Is Wrong (Lulu, 2017).

44. Holland, D. S. \& Jannot, J. E. Bycatch risk pools for the US West Coast Groundfish fishery. Ecol. Econ. 78, 132-147 (2012).

45. Humphreys, B. R. \& Perez, L. Syndicated play in lottery games. J. Socio Econ. 45, 124-131 (2013)

46. Selmier, W. T. An institutional perspective on governance, power and politics of financial risk. Bus. Politics 19, 215-240 (2017).

47. Rajan, R. G. Has financial development made the world riskier? Eur. Financial Manag. 12, 499-533 (2006).

48. De Weerdt, J. \& Dercon, S. Risk-sharing networks and insurance against illness. J. Dev. Econ. 81, 337-356 (2006).

49. Fafchamps, M. \& Gubert, F. Contingent loan repayment in the Philippines. Econ. Dev. Cult. Change 55, 633-667 (2007).

50. De Weerdt, J. \& Fafchamps, M. Social identity and the formation of health insurance networks. J. Dev. Stud. 47, 1152-1177 (2011).

51. Fafchamps, M. in Handbook of Social Economics Vol. 1B (eds Benhabib, J. et al.) 1255-1279 (Elsevier, 2011)

52. Coate, S. \& Ravallion, M. Reciprocity without commitment: characterization and performance of informal insurance arrangements. J. Dev. Econ. 40, 1-24 (1993).

53. Fafchamps, M. \& Lund, S. Risk-sharing networks in rural Philippines. J. Dev. Econ. 71, 261-287 (2003).

54. Genicot, G. \& Ray, D. Group formation in risk-sharing arrangements. Rev. Econ. Stud. 70, 87-113 (2003).

55. Hayashi, F., Altonji, J. \& Kotlikoff, L. Risk-sharing between and within families. Econometrica 64, 261-294 (1996).

56. Ligon, E. Risk sharing and information in village economies. Rev. Econ. Stud. 65, 847-864 (1998).

57. Ligon, E., Thomas, J. P. \& Worrall, T. Informal insurance arrangements with limited commitment: theory and evidence from village economies. Rev. Econ. Stud. 69, 209-244 (2002).

58. Townsend, R. M. Risk and insurance in village India. Econometrica 62, 539-591 (1994).

59. Morduch, J. Income smoothing and consumption smoothing. J. Econ. Perspect. 9, 103-114 (1995).

60. Davies, J. \& Bennett, R. Livelihood adaptation to risk: constraints and opportunities for pastoral development in Ethiopia's Afar region. J. Dev. Stud. 43, 490-511 (2007).

61. Barr, A. \& Genicot, G. Risk sharing, commitment, and information: an experimental analysis. J. Eur. Econ. Assoc. 6, 1151-1185 (2008).

62. Dekker, M. Risk, Resettlement and Relations: Social Security in Rural Zimbabwe Vol. 331 (Rozenberg Publishers, 2004).

63. Howe, E. L., Murphy, J. J., Gerkey, D. \& West, C. T. Indirect reciprocity, resource sharing, and environmental risk: evidence from field experiments in Siberia. PLoS ONE 11, e0158940 (2016).

64. Moritz, M. et al. Social risk-management strategies in pastoral systems: a qualitative comparative. Anal. Cross Cult. Res. 45, 286-317 (2011).

65. Moritz, M. Livestock transfers, risk management, and human careers in a West African pastoral system. Hum. Ecol. 41, 205-219 (2013).

66. Cashdan, E. (ed.) Risk and Uncertainty in Tribal and Peasant Economies (Westview Press, 1990)

67. Kaplan, H., Hill, K. \& Hurtado, A. M. in Risk And Uncertainty In Tribal And Peasant Economies (ed. Cashdan, E.) 107-143 (Westview Press, 1990).

68. Hames, R. in Adaptation and Human Behavior: An Anthropological Perspective (ed. Cronk, L.) 397-416 (Aldine de Gruyter Hawthorne, 2000).

69. Gurven, M., Allen-Arave, W., Hill, K. \& Hurtado, M. 'It's a life': signaling generosity among the Ache of Paraguay. Evol. Hum. Behav. 21, 263-282 (2000).

70. Gurven, M. \& Hill, K. Why do men hunt? A reevaluation of 'man the hunter' and the sexual division of labor. Curr. Anthropol. 50, 51-74 (2009).

71. Gurven, M. \& Hill, K. Moving beyond stereotypes of men's foraging goals: a reply to Hawkes, O'connell, and Coxworth. Curr. Anthropol. 51, 265-267 (2010).

72. Bliege Bird, R., Bird, D. W., Smith, E. A. \& Kushnick, G. C. Risk and reciprocity in Meriam food sharing. Evol. Hum. Behav. 23, 297-321 (2002).

73. Kaplan, H. \& Hill, K. Food sharing among Ache foragers: tests of explanatory hypotheses. Curr. Anthropol. 26, 223-246 (1985).
74. Winterhalder, B. Diet choice, risk, and food sharing in a stochastic environment. J. Anthropol. Archaeol. 5, 369-392 (1986).

75. Ember, C. R., Skoggard, I., Ringen, E. J. \& Farrer, M. Our better nature: does resource stress predict beyond-household sharing? Evol. Hum. Behav. 39, 380-391 (2018).

76. Bhattamishra, R. \& Barrett, C. B. Community-based risk management arrangements: a review. World Dev. 38, 923-932 (2010).

77. Platteau, J.-P. in Social Security in Developing Countries (eds Ahmad, E. et al.) 112-170 (Clarendon Press, 1991).

78. Platteau, J.-P. in Handbook of the Economics of Giving, Altruism and Reciprocity: Foundations (eds Kolm, S.-E. \& Ythier, J. E.) Ch. 12 (Elsevier Science \& Technology, 2006).

79. Stavropoulou, M., Holmes, R. \& Jones, N. Harnessing informal institutions to strengthen social protection for the rural poor. Glob. Food Sec. 12, 73-79 (2017).

80. Habtom, G. K. \& Ruys, P. Traditional risk-sharing arrangements and informal social insurance in Eritrea. Health Policy 80, 218-235 (2007).

81. Ostrom, E. Governing the Commons: The Evolution of Institutions for Collective Action (Cambridge Univ. Press, 1990).

82. Cronk, L., Guevara Beltrán, D., Mercado, D.L. \& Aktipis, A. 'A solidarity-type world': need-based helping among ranchers in the southwestern United States. Hum. Nat. (in the press).

83. Aarøe, L. \& Petersen, M. B. Crowding out culture: Scandinavians and Americans agree on social welfare in the face of deservingness cues. J. Polit. 76, 684-697 (2014).

84. Woodburn, J. in Property Relations: Renewing the Anthropological Tradition (ed. Hann, C. M.) 48-63 (Cambridge Univ. Press, 1998).

85. Rival, L. M. in The Cambridge Encyclopedia of Hunter Gatherers (eds Lee, R. B. \& Daly, R.) 101-104 (Cambridge Univ. Press, 1999).

86. Aktipis, A., Cronk, L. \& de Aguiar, R. Risk-pooling and herd survival: an agent-based model of a Maasai gift-giving system. Hum. Ecol. 39, 131-140 (2011).

87. Aktipis, A. et al. Cooperation in an uncertain world: for the Maasai of East Africa, need-based transfers outperform account-keeping in volatile environments. Hum. Ecol. 44, 353-364 (2016).

88. Campenni, M., Cronk, L. \& Aktipis, A. Correlated disasters and need-based transfers: the limits of risk pooling systems in simulated ecologies. Preprint at bioRxiv https://doi.org/10.1101/230607 (2017).

89. Hegmon, M. Risk reduction and variation in agricultural economies: a computer simulation of Hopi agriculture. Res. Econ. Anthropol. J. 11, 89-121 (1989).

90. Smith, E. A. et al. Wealth transmission and inequality among huntergatherers. Curr. Anthropol. 51, 19-34 (2010).

91. Claessens, S., Ayers, J. D., Cronk, L. \& Aktipis, A. Need-based transfer systems are more vulnerable to cheating when resources are hidden. Evol. Hum. Behav. 42, 104-112 (2021).

92. Aktipis, A. Know when to walk away: contingent movement and the evolution of cooperation. J. Theor. Biol. 231, 249-260 (2004).

93. Nair, M. Caste as self-regulatory club: evidence from a private banking system in nineteenth century India. J. Institutional Econ. 12, 677-698 (2016).

94. Selmier, W. T. Social capital and folk lending in China's hottest financial market. Econ. Political Stud. 6, 69-90 (2018).

95. Majekodunmi, A. O. Social transitions in the savannah: the decline and fall of social risk management amongst Fulani in the subhumid zone of Nigeria. Int. J. Soc. Econ. 45, 535-547 (2018).

96. Giroux, S. A. et al. Environmental heterogeneity and commodity sharing in smallholder agroecosystems. PLoS ONE 15, e0228021 (2020).

97. Allen, F. \& Babus, A. in The Network Challenge: Strategy, Profit, and Risk in an Interlinked World (eds Kleindorfer, P. R. \& Wind, Y. J) Ch. 21 (Wharton School Press, 2009).

98. Waller, R. in The Ecology Of Survival: Case Studies From Northeast African History (eds Johnson, D. H. \& Anderson, D. M.) 73-114 (Lester Crook Academic Publishing, 1988).

99. Townsend, C., Aktipis, A., Balliet, D. \& Cronk, L. Generosity among the Ik of Uganda. Evolut. Hum. Sci. 2, e23 (2020).

100. Turnbull, C. Mountain People (Simon and Schuster, 1972).

101. Heine, B. The Mountain People: some notes on the Ik of North-eastern Uganda. Africa 55, 3-16 (1985).

102. Irons, W. in Evolution and the Capacity for Commitment (ed. Nesse, R. M.) 292-309 (Russel Sage Foundation, 2001).

103. Sosis, R. \& Bressler, E. R. Cooperation and commune longevity: a test of the costly signaling theory of religion. Cross Cult. Res. 37, 211-239 (2003).

104. Sosis, R. \& Ruffle, B. J. Religious ritual and cooperation: testing for a relationship on Israeli religious and secular kibbutzim. Curr. Anthropol. 44, 713-722 (2003).

105. Soler, M. Costly signaling, ritual and cooperation: evidence from Candomblé, an Afro-Brazilian religion. Evol. Hum. Behav. 33, 346-356 (2012). 
106. Cronk, L. \& Aktipis, A. Sacredness as an implied threat of supernatural punishment: the case of need-based transfers. Relig. Brain Behav. 8, 282-285 (2017).

107. Hamilton, W. D. The genetical evolution of social behavior I. J. Theor. Biol. 7, 1-16 (1964)

108. Hamilton, W. D. The genetical evolution of social behaviour. II. J. Theor Biol. 7, 17-52 (1964)

109. Aktipis, A., Cronk, L., Alcock, J., Ayers, J. D. \& Baciu, C. Understanding cooperation through fitness interdependence. Nat. Hum. Behav. 2, 429-431 (2018).

110. Roberts, G. Cooperation through interdependence. Anim. Behav. 70, 901-908 (2005).

111. Aktipis, A. Principles of cooperation across systems: from human sharing to multicellularity and cancer. Evol. Appl. 9, 17-36 (2016).

112. Ichikawa, M. in Cash Commoditization and Changing Foragers Vol. 3 (eds Peterson N. \& Matsuyana, T.) 135-162 (Senri Ethnological Studies, 1991).

113. Kitanishi, K. The impact of cash and commoditization on the Baka hunter-gatherer society in Southeastern Cameroon. Afr. Study Monogr. 33, 121-142 (2006).

114. Townsend, C. M. The Emergence of Inequality in a Former Hunter-Gatherer Society: A Baka Case Study. PhD thesis, Univ. College London (2016).

115. Baird, T. D. \& Gray, C. L. Livelihood diversification and shifting social networks of exchange: a social network transition? World Dev. 60, 14-30 (2014).

116. Udry, C. Credit markets in northern Nigeria: credit as insurance in a rural economy. World Bank Econ. Rev. 4, 251-269 (1990).

117. Udry, C. Risk and insurance in a rural credit market: an empirical investigation in northern Nigeria. Rev. Econ. Stud. 61, 495-526 (1994).

118. Platteau, J. \& Abraham, A. An inquiry into quasi-credit contracts: the role of reciprocal credit and interlinked deals in small-scale fishing communities. J. Dev. Stud. 23, 461-490 (1987).

119. Fafchamps, M. \& Gubert, F. The formation of risk sharing networks. J. Dev. Econ. 83, 326-350 (2007)

120. Skees, J. R. \& Barnett, B. J. Enhancing microfinance using index-based risk-transfer products. Agric. Finance Rev. 66, 235-250 (2006).

121. Takahashi, K., Barrett, C. B. \& Ikegami, M. Does index insurance crowd in or crowd out informal risk sharing? Evidence from rural Ethiopia. Am. J. Agric. Econ. 101, 672-691 (2018)

122. Bertram-Huemmer, V. \& Kraehnert, K. Does index insurance help households recover from disaster? Evidence from IBLI Mongolia. Am. J. Agric. Econ. 100, 145-171 (2018)

123. Solnit, R. A Paradise Built in Hell: The Extraordinary Communities That Arise in Disaster (Penguin, 2010).

124. Wallace-Wells, B. Why does America need the Cajun Navy? The New Yorker (31 August 2017)

125. Kaur, H. \& Luhby, T. People around the country are sewing masks. And some hospitals, facing dire shortage, welcome them. CNN.com (24 March 2020).

126. Broadway, C. Shopping Angels' help those at high risk during pandemic. YouTube https://www.youtube.com/watch?v=loLKMbXvUDg (2020).

127. Albrecht, L. Meet the people who are donating their $\$ 1,200$ stimulus checks to charity: 'It's not really my money, it's our money'. MarketWatch.com (20 April 2020).

128. Morris-Guity and Adam, J. 'Don't worry about paying me': NYC landlord waives rent because of coronavirus. NBCNew York.com (1 April 2020).

129. de Rugy, V. Coronavirus pandemic inspires private generosity. Reason.com (19 March 2020).

130. Taleb, N. N. The Black Swan: The Impact of the Highly Improbable (Random House, 2007).
131. Ferguson, A. An Essay on the History of Civil Society, 1767 (Cambridge Univ. Press, 1966).

132. Hayek, F. A. Law, Legislation and Liberty, Volume 1: Rules and Order (Univ. Chicago Press, 1978).

133. Endicott, K. in The Cambridge Encyclopedia of Hunters and Gatherers (eds Lee, R. B. \& Daly, R.) 298-302 (Cambridge Univ. Press, 1999).

134. Ziker, J. P. Peoples of the Tundra: Northern Siberians in the Post-Communist Transition (Waveland Press, 2002).

135. Sahlins, M. D. Moala: Culture and Nature on a Fijian Islands (Univ. Michigan Press, 1962).

136. Radcliffe-Brown, A. R. The Andaman Islanders (Cambridge Univ. Press, 1922).

137. Arcand, B. in The Cambridge Encyclopedia of Hunter Gatherers (eds Lee, R. B. \& Daly, R.) 97-100 (Cambridge Univ. Press, 1999).

138. Iyer, K. P. Risk Management through Social Networks Among Male and Female Pastoralists in Karamoja, Uganda. PhD thesis, Rutgers Univ. (2016).

139. Gerkey, A. P. From State Collectives to Local Commons: Cooperation and Collective Action Among Salmon Fishers and Reindeer Herders in Kamchatka, Russia. PhD thesis, Rutgers Univ. (2010).

140. Howell, N. Life Histories of the Dobe !Kung: Food, Fatness, and Well-being Over the Life Span (Univ. California Press, 2010).

141. Rogers, E. S. in Hunters and Gatherers Today: A Socioeconomic Study of Eleven such Cultures in the Twentieth Century (ed. Bicchieri, M. G.) 90-137 (Holt, Rinehart and Winston, 1972).

142. Bird-David, N. in The Cambridge Encyclopedia of Hunter Gatherers (eds Lee, R. B. \& Daly, R.) 257-260 (Cambridge Univ. Press, 1999).

143. Pandya, V. Above the Forest: A Study of Andamanese Ethnoanemology, Cosmology, and the Power of Ritual (Oxford Univ. Press, 1993).

144. Myers, F. R. in The Cambridge Encyclopedia of Hunter Gatherers (eds Lee, R. B. \& Daly, R.) 348-352 (Cambridge Univ. Press, 1999).

145. Gordillo, G. N. in The Cambridge Encyclopedia of Hunter Gatherers (eds Lee, R. B. \& Daly, R.) 110-113 (Cambridge Univ. Press, 1999).

146. Price, J. A. Sharing: the integration of intimate economies. Anthropologica 17, 3-27 (1975)

\section{Acknowledgements}

This work was conducted as part of The Human Generosity Project (http:// humangenerosity.org), which has received support from the National Science Foundation, the John Templeton Foundation, the Charles Koch Foundation, Arizona State University, Rutgers University's Center for Human Evolutionary Studies and the American Center for Mongolian Studies. Any opinions, findings, conclusions or recommendations expressed in this material are those of the authors and do not necessarily reflect the views of our funders.

\section{Competing interests}

The authors declare no competing interests.

\section{Additional information}

\section{Correspondence should be addressed to L.C.}

Peer review information Nature Human Behaviour thanks Travis Selmier and the other anonymous, reviewer(s) for their contribution to the peer review of this work.

Reprints and permissions information is available at www.nature.com/reprints.

Publisher's note Springer Nature remains neutral with regard to jurisdictional claims in published maps and institutional affiliations.

(c) Springer Nature Limited 2021 